\title{
Diametral tensile strength and film thickness of an experimental dental luting agent derived from castor oil
}

\author{
Juliana Cabrini CARMELLO' ${ }^{1}$, Laiza Maria Grassi FAIS ${ }^{2}$, Lígia Nunes de Moraes RIBEIRO³, Salvador CLARO NETO, \\ Dalton Geraldo GUAGLIANONI ${ }^{5}$, Lígia Antunes Pereira PINELLI ${ }^{6}$
}

\begin{abstract}
1- DDS, MSc, Graduate student, Department of Dental Materials and Prosthodontics, Araraquara Dental School, UNESP - Univ. Estadual Paulista, Araraquara, SP, Brazil.

2- DDS, MSc, PhD, Department of Dental Materials and Prosthodontics, Araraquara Dental School, UNESP - Univ. Estadual Paulista, Araraquara, SP, Brazil. 3- DDS, Department of Dental Materials and Prosthodontics, Araraquara Dental School, UNESP - Univ. Estadual Paulista, Araraquara, SP, Brazil.

4- PhD, Department of Chemistry and Molecular Physics, Institute of Chemistry of São Carlos, University of São Paulo, São Carlos, SP, Brazil.

5- PhD, Department of Education, College of Letters and Science, UNESP - Univ. Estadual Paulista, São Paulo, SP, Brazil.

6- DDs, MSc, PhD, Assistant Professor, Department of Dental Materials and Prosthodontics, School of Dentistry of Araraquara, UNESP - Univ. Estadual Paulista, Araraquara, SP, Brazil.
\end{abstract}

Corresponding address: Lígia Antunes Pereira Pinelli - Rua Humaitá, 1680 - Centro - Araraquara - SP - Brasil - 14801-903 - Phone: +55 16 $3301-6413$ Fax: +55 16 3301-6406 - e-mail: ligia@foar.unesp.br

Received: November 4, 2009 - Modification: August 16, 2011 - Accepted: September 18, 2011

\section{ABSTRACT}

\begin{abstract}
The need to develop new dental luting agents in order to improve the success of treatments has greatly motivated research. Objective: The aim of this study was to evaluate the diametral tensile strength (DTS) and film thickness (FT) of an experimental dental luting agent derived from castor oil (COP) with or without addition of different quantities of filler (calcium carbonate - $\mathrm{CaCO}_{3}$ ). Material and Methods: Eighty specimens were manufactured (DTS $\mathrm{N}=40 ; \mathrm{FT} \mathrm{N}=40$ ) and divided into 4 groups: Pure COP; COP 10\%; COP 50\% and zinc phosphate (control). The cements were mixed according to the manufacturers' recommendations and submitted to the tests. The DTS test was performed in the MTS 810 testing machine $(10 \mathrm{KN}, 0.5 \mathrm{~mm} / \mathrm{min})$. For FT test, the cements were sandwiched between two glass plates $\left(2 \mathrm{~cm}^{2}\right)$ and a load of $15 \mathrm{~kg}$ was applied vertically on the top of the specimen for $10 \mathrm{~min}$. The data were analyzed by means of one-way ANOVA and Tukey's test $(\alpha=0.05)$. Results: The values of DTS (MPa) were: Pure COP- 10.94 1.30;

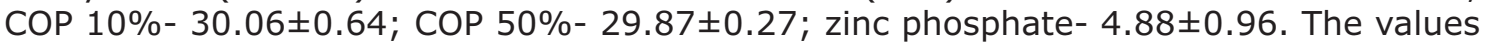

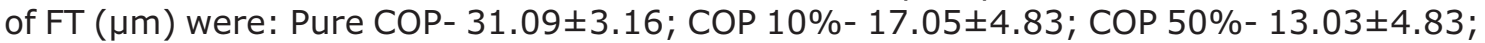
Zinc Phosphate- 20.00 \pm 0.12 . One-way ANOVA showed statistically significant differences among the groups (DTS - $p=1.01 \mathrm{E}-40 ; \mathrm{FT}-\mathrm{p}=2.4 \mathrm{E}-10$ ). Conclusion: The experimental dental luting agent with $50 \%$ of filler showed the best diametral tensile strength and film thickness.
\end{abstract}

Key words: Dental prosthesis. Biocompatible materials. Ricinus communis. Calcium carbonate. Zinc phosphate cement. Tensile strength.

\section{INTRODUCTION}

In the past, traditional dental luting agents such as zinc phosphate were commonly used for cementation of crowns ${ }^{21}$. In spite of disadvantages, such as solubility, lack of retention and low $\mathrm{pH}^{7}$, this luting agent has been successfully used ${ }^{26}$ and was the most researched cement for over a century.
Nowadays, some new adhesive luting agents have been tested in order to reduce microleakage, increase retention, and improve physical properties.

Currently, vegetable polyurethanes, which combine the versatility of polymer formulation with the global concern in producing new biomaterials through resources that preserve the environment, became one of the main studied categories of 
materials ${ }^{2}$. In dentistry, membrane material ${ }^{20}$, sealers ${ }^{17,23,24}$ and irrigating solution ${ }^{18}$ were developed from vegetable polyurethane obtained from castor oil. Additionally, since this polyurethane has been described as being biocompatible, osteoconductor, osteoinductor, antimicrobial, osseointegrable and absorbable ${ }^{8,16}$, it has been used in bone prosthesis, alveolar healing and plastic surgery ${ }^{16}$. In a study conducted by Camargo, et al. ${ }^{3}$ (2010), the castor oil bean showed less inflammatory response in subcutaneous tissue of rats when compared with calcium hydroxide cement.

This polyurethane has elasticity, good compatibility, versatility, composition and structure that can be modified in accordance with specific requirements ${ }^{27}$, characteristics that enable great applicability in the biomedical area and open a new field to the development of dental luting agents. In addition to the innumerable uses of the castor oil, the plant from which it is extracted can be found in many parts of the world. It is greatly exploited in Brazil and India ${ }^{9}$, and can be produced on a large scale, which makes it interesting from an economic and ecological point of view.

In the oral environment, dental luting agents must withstand masticatory and parafunctional stresses in different clinical situation ${ }^{6,13}$. They should maintain their integrity while transferring stresses from crowns or fixed partial dentures to tooth structure. Once the retention of crowns is intimately related to mechanical properties of the dental luting agents, the strength of these materials associated to the ability of resisting crack propagation ${ }^{4}$, which causes ruptures, can predict the clinical success. Resistant dental luting agents provide better stress distribution, less probability of compressive or tensile failures and great probability of clinical success ${ }^{25}$.

Diametral tensile strength (DTS) is a mechanical property that must be assessed ${ }^{4}$ because several cements are extremely friable and have a susceptibility to mechanical failure ${ }^{28}$. This test is widely used due to its relative simplicity and reproducible results. Additionally, it is the most common method for assessing the tensile strength of friable materials because it avoids the difficulties inherent to the flexural tensile strength test ${ }^{1}$.

In addition to the mechanical properties, physical properties, such as film thickness (FT) of luting agents, can directly affect long-term clinical success. Dental cements should not exhibit a very high FT. Current ISO standards require a FT at the time of seating inferior to $25 \mu \mathrm{m}$ for water-based luting cements ${ }^{12}$, and no greater than $50 \mu \mathrm{m}$ for resin-based cements ${ }^{11}$. Low FT can improve seating and decrease marginal gaps; whereas improved marginal adaptation can also reduce plaque accumulation, periodontal disease and cement dissolution ${ }^{29}$. So, the purpose of this study was to compare the DTS and FT of an experimental polyurethane dental luting agent derived from castor oil with traditional zinc phosphate cement.

\section{MATERIAL AND METHODS}

The materials with their nomenclature, manufacturers and composition are listed in Figure 1. All materials were proportioned and mixed according to the manufacturers' instructions. Forty specimens were manufactured for DTS test and 40 specimens for FT test.

The castor oil polyurethane (COP) was supplied

\begin{tabular}{|c|c|c|}
\hline Groups & Manufacturer & Composition \\
\hline Pure COP* & $\begin{array}{l}\text { Poliquil Araraquara- Polímeros Químicos Ltda, } \\
\text { Araraquara, São Paulo, Brazil }\end{array}$ & $\begin{array}{l}\text { Polyol: tri-functional polyester (castor oil) } \\
370 \mathrm{mgKOH} / \mathrm{g} \\
\text { Prepolymer: } \mathrm{MDI}^{* *}\end{array}$ \\
\hline $\mathrm{COP}^{*} 10 \%$ & $\begin{array}{l}\text { Poliquil Araraquara- Polímeros Químicos Ltda, } \\
\text { Araraquara, São Paulo, Brazil }\end{array}$ & $\begin{array}{l}\text { Polyol: tri-functional polyester (castor oil) } \\
370 \mathrm{mgKOH} / \mathrm{g} \\
\text { Prepolymer: } \mathrm{MDI}^{* *} \\
\text { Powder (filler): } \mathrm{CaCO}_{3} 10 \% \mathrm{w} / \mathrm{w}\end{array}$ \\
\hline $\mathrm{COP}^{*} 50 \%$ & $\begin{array}{l}\text { Poliquil Araraquara- Polímeros Químicos Ltda, } \\
\text { Araraquara, São Paulo, Brazil }\end{array}$ & $\begin{array}{l}\text { Polyol: tri-functional polyester (castor oil) } \\
370 \text { mgKOH/g } \\
\text { Prepolymer: } \mathrm{MDI}^{* *} \\
\text { Powder (filler): } \mathrm{CaCO}_{3} 10 \% \mathrm{w} / \mathrm{w}\end{array}$ \\
\hline Zinc Phosphate & SS White, Rio de Janeiro, Rio de Janeiro, Brazil & $\begin{array}{l}\text { Powder: Zinc oxide + Magnesium oxide } \\
\text { Liquid: Phosphoric acid + aluminum hydroxide } \\
+ \text { Zinc oxide + Distilled water }\end{array}$ \\
\hline
\end{tabular}

Figure 1- Experimental groups, manufacturers and compositions of materials used in this study ${ }^{*} \mathrm{COP}=$ Castor oil poliurethane; ${ }^{* *} \mathrm{MDI}=$ methylene diphenyl disocyanato 
in sachet. Pure COP contained the prepolymer and polyol separately, while COP $10 \%$ and COP $50 \%$ included another separation containing $10 \%$ or $50 \%$ in weight of filler (calcium carbonate $-\mathrm{CaCO}_{3}$ ), respectively. The quantity of filler, in \% weight, was determined by the manufacturer in relation to the sum of the polyol and the prepolymer weights. The mixing method of COP groups includes $2 \mathrm{~min}$ of manual mixing into the sachet and other 2 min of mixing with a spatula on a Teflon plate to obtain the final material (Figure 2).

Zinc phosphate was mixed within $90 \mathrm{~s}$ with a spatula following the incremental technique. The proportion of $1.4 \mathrm{~g} / 0.4 \mathrm{~mL}$ recommended by the manufacturer was converted to $1.4 \mathrm{~g}$ of powder/1.54 g of liquid.

DTS Test: it was conducted with 40 cylindrical specimens $(6.0 \mathrm{~mm}$ in diameter $\times 3.0 \mathrm{~mm}$ in height) divided into the 4 experimental groups $(n=10)$. Immediately after the mixing, the materials were inserted in a Teflon mold, which was put in a mechanical press under constant load in an atmosphere of $100 \%$ relative humidity at $37^{\circ} \mathrm{C}$ for $1 \mathrm{~h}^{1}$. Subsequently, all specimens were finished and polished with 400-grit abrasive SiC papers (BuehlerMet Abrasive Papers, Buehler, Lake Bluff, IL, USA) and were stored in distilled water at $37^{\circ} \mathrm{C}$ for $24 \mathrm{~h}$ before the mechanical test. The specimens were subjected to a compressive load $(10 \mathrm{KN})$ in a universal testing machine (MTS-810 Material Test System, Eden Praire, MN, USA) at a crosshead speed of $0.5 \mathrm{~mm} / \mathrm{min}$ until fracture. The results were recorded and transformed in tensile

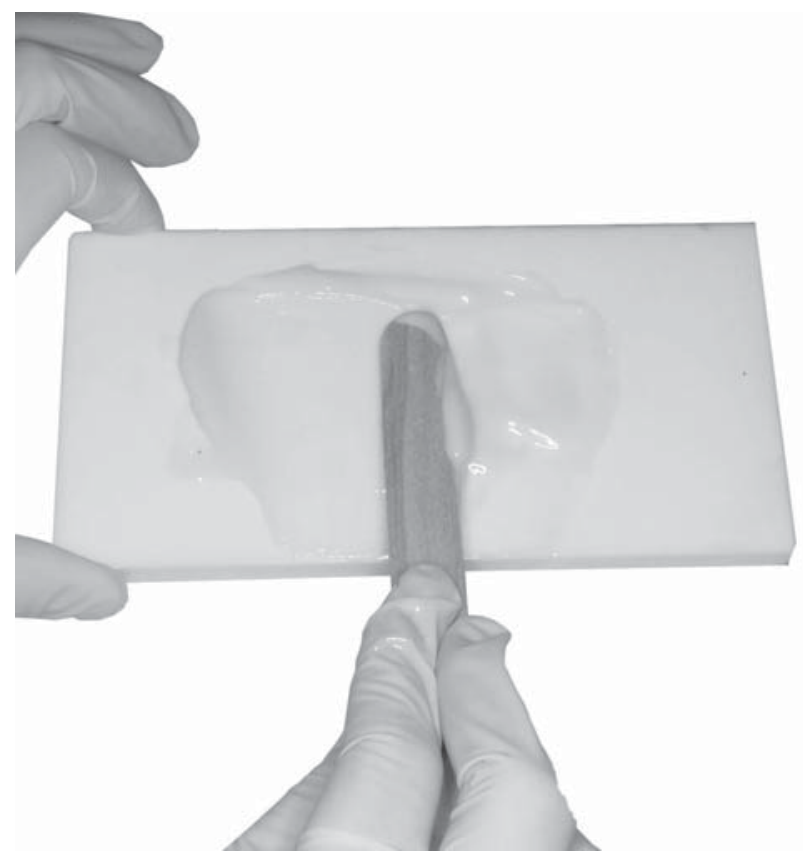

Figure 2- Homogeneous paste of castor oil polyurethane (COP) obtained after manual mixing and mixing with a spatula on a Teflon plate values (MPa) by the computer software (Test Star II, International Business Machines Corporation IBM, Armonk, NY, USA), connected to the system. The results were submitted to one-way ANOVA and Tukey's test $(\alpha=0.05)$ in order to compare the values of DTS among the 4 experimental groups.

FT test: it was conducted with 40 specimens divided into the 4 experimental groups $(n=10)$. The method for determining FT was described in ISO $9917^{19,33}$. For Pure COP, COP $10 \%$ and COP $50 \%$, immediately after the mixing, the dental luting agent was sandwiched between two uniform thickness glass plates $\left(2 \mathrm{~cm}^{2}\right)$ with faces precisely parallels. A load of $15 \mathrm{~kg}$ was applied vertically on the top of the glass plate. After $10 \mathrm{~min}$, the thickness of the two plates with cement was determined using a micrometer (Absolute Digimatic Micrometer 227, Mitutoyo Sul America Ltda, Suzano, SP, Brazil). The FT of the cement was calculated by subtracting the thickness of the glasses without the mixed material from the overall thickness. For zinc phosphate group, after 3 min of the beginning of the mixture, the cement was inserted between the two glass plates and submitted to the FT test as cited above.

Table 1- Diametral tensile strength (MPa) of dental luting agents and standard deviations

\begin{tabular}{cc}
\hline Groups & DTS \\
\hline Pure COP $^{*}$ & $10.94(1.30)^{\mathrm{B}}$ \\
COP 10\% & $30.06(0.64)^{\mathrm{A}}$ \\
COP $50 \%$ & $29.87(0.27)^{\mathrm{A}}$ \\
Zinc phosphate & $4.88(0.96)^{\mathrm{C}}$ \\
\hline
\end{tabular}

Different uppercase letters indicate significant differences by one-way ANOVA followed by HSD Tukey test

One-way ANOVA $(p=1.01 \mathrm{E}-4)$

* COP = Castor oil polyurethane

DTS= Diametral tensile strenght

Table 2- Film thicknesses $(\mu \mathrm{m})$ of dental luting agents and standard deviations

\begin{tabular}{ll}
\hline Groups & Film thickness \\
\hline Pure COP* & $31.09(3.16)^{\mathrm{C}}$ \\
COP $10 \%$ & $17.05(4.83)^{\mathrm{AB}}$ \\
COP 50\% & $13.03(4.83)^{\mathrm{A}}$ \\
Zinc phosphate & $20.00(0.12)^{\mathrm{B}}$ \\
\hline
\end{tabular}

Different uppercase letters indicate significant differences by one-way ANOVA followed by HSD Tukey test

One-way ANOVA $(p=2.4 E-10)$

${ }^{*} \mathrm{COP}=$ Castor oil polyurethane 


\section{RESULTS}

DTS and FT values of each material are given in Tables 1 and 2.

According to the statistical analysis, all COPs (Pure COP, COP 10\% and COP 50\%) demonstrated significantly higher $(P<0.05)$ DTS than zinc phosphate. The addition of the filler $\left(\mathrm{CaCO}_{3}-10 \%\right.$ and $50 \% \mathrm{w} / \mathrm{w}$ ) increased DTS. No significant differences $(P>0.05)$ were found between the DTS values of COP $10 \%$ and COP $50 \%$.

As shown in Table 2, FT values of COP $10 \%$, COP $50 \%$ and zinc phosphate were inferior to $25 \mu \mathrm{m}$; only the Pure COP exceeded this value. There was a positive influence of filler addition in the $\mathrm{FT}$, since the comparisons Pure COP vs. COP $10 \%$, Pure COP vs. COP $50 \%$, COP $10 \%$ vs. COP $50 \%$ were minor than 0.05 i.e., the mean values of FT diminished as the quantity of filler was incorporated.

\section{DISCUSSION}

This research assessed DTS and FT of an experimental polyurethane dental luting agent derived from castor oil, pure or with different quantities of $\mathrm{CaCO}_{3}$, comparing then with zinc phosphate cement.

The zinc phosphate cement and COP differ each other because their viscous and elastic components; zinc phosphate is water-based cement which is more friable after the final setting reaction, while COP is a polymer similar to resinous cements. When submitted to tensile forces, COP shows a curve characteristic of polymers that undergo flow after the linear region of elasticity, with plastic deformation occurring until rupture.

The results showed that the addition of $\mathrm{CaCO}_{3}$ improves the DTS of COP independently of its percentage. Calcium carbonate diminishes the plastic deformation of COP causing an increase in the final resistance since this filler can fill any pores in the matrix, allowing the cement resists to higher loads. The presence of $\mathrm{CaCO}_{3}$ was also proven interesting because it provides radiopacity without affecting biocompatibility ${ }^{14}$.

Zinc phosphate cement had the lower DTS (4.88 $\mathrm{MPa}$ ) when compared with COP. DTS of COPs (COP $10 \%$ and COP $50 \%$ ) was higher than values of glass ionomer cement ( $18 \mathrm{MPa})^{25}$ and seems to be more close to the literature results of resin cements which ( $\approx 40-45 \mathrm{MPa})^{6,10,25,26}$.

With respect to $\mathrm{FT}$, there is no agreement on its minimum value, but values between 50-100 $\mu \mathrm{m}$ seem convenient ${ }^{19}$. The American Dental Association Specification $n^{\circ} .8$ restricts the zinc phosphate FT ranging from $25 \mu \mathrm{m}$ to $40 \mu \mathrm{m}^{5}$, but literature values of FT of a number of luting materials show that it can range from $10 \mu \mathrm{m}$ to $152 \mu \mathrm{m}$, depending on the nature of the material ${ }^{22}$.

The results of this study showed that all evaluated dental luting agents, except Pure COP, had FT means inferior to $25 \mu \mathrm{m}$, meeting the relevant ISO standard ${ }^{11}$. The differences found among the FT of the evaluated materials may be explained by the nature and composition of them. While the setting of zinc phosphate cement occurs by means of a water-based reaction with the growth of the crystalline network of the zinc phosphate ${ }^{10}$, the polymerization of COP includes a moisture curing kinetics which is determined by a reaction between the isocyanate and hydroxyl groups, showing a volumetric expansion and consequently higher FT. The obtained results of zinc phosphate $(20.04 \mu \mathrm{m})$ are in agreement previous studies $^{21}$. Pure COP produced FT above the $25 \mu \mathrm{m}$ recommended by ISO standard.

FT of COP diminished with the addition of $\mathrm{CaCO}_{3}$ making it lesser than that of some resin cements ${ }^{15}$. Considering that the volumetric expansion is linked to the quantity of organic matrix and that the experimental cement may be composed by only organic matrix (Pure COP) or by an organic matrix with mineral filler $\left(\mathrm{COP}+\mathrm{CaCO}_{3}\right)$, the incorporation of filler diminishes the expansion and consequently provides better FT values.

Despite the clinical importance of the two properties evaluated in this study, the assessment of single properties is not sufficient to identify the best dental luting agent. However, if an experimental dental luting agent does not have appropriate FT and DTS it will not allow the prosthesis serves the functions adequately over a long period. Among the various materials used for cementing indirect restorations and fixed dental prostheses, there is not a single one that fulfills all the characteristics considered ideal. Although one of the experimental materials tested in this study provided better results compared with zinc phosphate cement, further research is required. Comparison with other cements and evaluation of other properties, such as adhesion, hydrolytic degradation and microleakage, can be the focus of future researches. Finally, the introduction of new materials, particularly those not derived from petroleum will enrich the available arsenal of luting materials.

\section{CONCLUSION}

Within the limitations of this study, it was conclude that:

1) The polyurethane dental luting agent derived from castor oil (COP) with the addition of $\mathrm{CaCO}_{3}$ filler showed better values of DTS and FT when compared with zinc phosphate cement.

2) For both DTS and FT, the best composition of the experimental polyurethane dental luting agent 
was the one with the addition of $50 \% \mathrm{w} / \mathrm{w}$ of $\mathrm{CaCO}_{3}$

\section{ACKNOWLEDGEMENTS}

The authors of this paper thank to FAPESP for financial support (grants 06/02821-8; 06/00082-3; 07/02441-3)

\section{REFERENCES}

1- Ban S, Anusavice KJ. Influence of test method on failure stress of brittle dental materials. J Dent Res. 1990;69(12):1791-9.

2- Bao H, Zhang Z, Ying S. Effect of ionic group on the behaviour of polyurethaneurea emulsion. Polymer. 1996;37(13):2751-4.

3- Camargo SE, Rode SM, Prado RF, Carvalho YR, Camargo $\mathrm{CH}$. Subcutaneous tissue reaction to castor oil bean and calcium hydroxide in rats. J Appl Oral Sci. 2010;18(3):273-8.

4- Cattani-Lorente MA, Godin C, Meyer JM. Early strength of glass ionomer cements. Dent Mater. 1993;9(1):57-62.

5- Council on Dental Materials and Devices. Council adopts American Dental Association Specification No. 8 (dental zinc phosphate cement) and 11 (agar impression material). J Am Dent Assoc. $1967 ; 74(7): 1565-73$.

6- Della Bona A, Benetti P, Borba M, Cecchetti D. Flexural and diametral tensile strength of composite resins. Braz Oral Res. 2008;22(1):84-9.

7- Diaz-Arnold AM, Vargas MA, Haselton DR. Current status of luting agents for fixed prosthodontics. J Prosthet Dent. 1999;81(2):135-41.

8- Ferreira CM, Rosa OPS, Torres SA, Ferreira FB, Bernardinelli N. Activity of endodontic antibacterial agents against selected anaerobic bacteria. Braz Dent J. 2002;13(2):118-22.

9- Ferreira P, Pereira R, Coelho JF, Silva AF, Gil MH. Modification of the biopolymer castor oil with free isocyanate groups to be applied as bioadhesive. Int J Biol Macromol. 2007;40(2):144-52. 10- Fonseca RG, Artusi TP, Santos JG, Adabo GL. Diametral tensile strength of dual-curing resin cements submitted exclusively to autopolymerization. Quintessence Int. 2007;38(9):e527-31.

11- International Organization for Standardization. ISO 4049: Dentistry - Polymer-based restorative materials. Geneva: The Organization; 2009.

12- International Organization for Standardization. ISO 9917-1. Dentistry - Water-based cements - part 1: powder/liquid acid based cements. Geneva: The Organization; 2007.

13- Irie M, Suzuki K, Watts DC. Marginal and flexural integrity of three classes of luting cement, with early finishing and water storage. Dent Mater. 2004;20(1):3-11.
14- Jowett AK, Ferguson MW, Combe EC. In vitro biocompatibility testing: a new organ culture model. J Dent. 1988;16(2):55-65. 15- Kious AR, Roberts HW, Brackett WW. Film thicknesses of recently introduced luting cements. J Prosthet Dent. 2009;101(3):189-92.

16- Leite FR, Ramalho LT. Bone regeneration after demineralized bone matrix and castor oil (Ricinus communis) polyurethane implantation. J Appl Oral Sci. 2008;16(2):122-6.

17- Martins GR, Carvalho CA, Valera MC, Oliveira LD, Buso L, Carvalho AS. Sealing ability of castor oil polymer as a root-end filling material. J Appl Oral Sci. 2009;17(3):220-3.

18- Meneghin MP, Nomelini SM, Sousa-Neto MD, Marchesan MA, França SC, Santos HS. Morphologic and morphometric analysis of the root canal apical third cleaning after biomechanical preparation using $3.3 \%$ Ricinus communis detergent and $1 \% \mathrm{NaOCl}$ as irrigating solutions. J Appl Oral Sci. 2006;14(3):178-82.

19- Molin MK, Karlsson SL, Kristiansen MS. Influence of film thickness on joint bend strength of a ceramic/resin composite joint. Dent Mater. 1996;12(4):245-9.

20- Monteiro AS, Macedo LG, Macedo NL, Balducci I. Polyurethane and PTFE membranes for guided bone regeneration: histopathological and ultrastructural evaluation. Med Oral Patol Oral Cir Bucal. 2010;15(2):e401-6.

21- Osman SA, McCabe JF, Walls AW. Film thickness and rheological properties of luting agents for crown cementation. Eur J Prosthodont Restor Dent. 2006;14(1):23-7.

22- Pilo R, Cardash HS. In vivo retrospective study of cement thickness under crowns. J Prosthet Dent. 1998;79(6):621-5.

23- Pinheiro CR, Guinesi AS, Pizzolitto AC, Bonetti-Filho I. In vitro antimicrobial activity of Acroseal, Polifil and Epiphany against Enterococcus faecalis. Braz Dent J. 2009;20(2):107-11.

24- Rosa PC, Mancini MN, Camargo SE, Garrido AD, Camargo CH, Rode SM. Dimensional alterations and solubility of new endodontic sealers. Braz Dent J. 2010;21(4):301-4.

25- White SN, Yu Z. Compressive and diametral tensile strengths of current adhesive luting agents. J Prosthet Dent. 1993;69(6):56872.

26- White SN, Yu Z. Physical properties of fixed prosthodontic, resin composite luting agents. Int J Prosthodont. 1993;6(4):384-9. 27- Yaszemski MJ, Payne RG, Hayes WC, Langer R, Mikos AG. Evolution of bone transplantation: molecular, cellular and tissue strategies to engineer human bone. Biomaterials. $1996 ; 17(2): 175-85$.

28- Yettram AL, Wright KW, Pickard HM. Finite element stress analysis of the crowns of normal and restored teeth. J Dent Res. 1976;55(6):1004-11.

29- Yu Z, Strutz JM, Kipnis V, White SN. Effect of dynamic loading methods on cement film thickness in vitro. J Prosthodont. 1995;4(4):251-5. 